\title{
ASSESSMENT OF IMMUNOMODULATORY POTENTIAL OF AN AYURVEDIC FORMULATION, NIROCIL SYRUP IN WISTAR RATS
}

\section{DINESH DILIP GHADIGAONKAR ${ }^{1 *}$, MUKESH B CHAWDA ${ }^{2}$, KAPIL S THAKUR ${ }^{3}$}

${ }^{1}$ Shree Dhootapapeshwar Ayurvedic Research Foundation (A Division of Shree Dhootapapeshwar Ltd.), Panvel, Maharashtra, India ${ }^{2}$ Solumiks Herbaceuticals Ltd. (A Division of Shree Dhootapapeshwar Ltd.), Panvel, Maharashtra, India. ${ }^{3}$ Shree Dhootapapeshwar Ltd. Mumbai, Maharashtra, India. Email: bms@teamsdl.in

Received: 22 August 2020, Revised and Accepted: 15 August 2020

\section{ABSTRACT}

Objective: This study aims to assess the immunomodulatory potential of an Ayurvedic formulation, Nirocil syrup, in Wistar rats.

Methods: The experiments were conducted on Wistar rats with prior approval from the Institutional Animal Ethics Committee. Nirocil syrup was administered for 6 weeks to experimental animals. Parameters such as hemagglutination titer, histopathology of immunological organs, complete blood count, differential leukocyte count, and immunological paw edema were recorded and compared with controlled (untreated) and becozinc treated groups.

Results: Nirocil treated group significantly enhanced the antibody titer in comparison to the control group. The results are supported by the increase in blood lymphocyte count and antigenic stimulation in immunological organs (spleen). Nirocil syrup enhanced antibody formation and suppressed the immunological edema in experimental animals.

Conclusions: The study concludes that the Ayurvedic formulation Nirocil syrup has immunopotentiating activity.

Keywords: Immunopotentiating activity, Hemagglutination test, Rat paw edema, Ayurveda.

(C) 2020 The Authors. Published by Innovare Academic Sciences Pvt Ltd. This is an open access article under the CC BY license (http://creativecommons. org/licenses/by/4. 0/) DOI: http://dx.doi.org/10.22159/ajpcr.2020.v13i10.38826

\section{INTRODUCTION}

Ayurveda is a pleasing dream to the traditional system of medicine, which gives a deep perception of healthy life and longevity. The term Ayurveda can be simplified as Ayu (life) and Veda (knowledge), the science of life, and knowledge [1]. The basic principle of Ayurveda is to increase the natural resistance of the body against invading agents rather than directly acting against invasions. In the Ayurvedic system of medicines, herbs are commonly used to improve the overall resistance of the body against common infections and pathogens with immunomodulatory effects [2]. The mechanism of immunomodulation is to adjust the host immune system either by immunostimulation or immunosuppression. Hence, immunomodulators are recognized as biological response modifiers, which boost the defense mechanism of the host [3,4].

Nirocil syrup is an Ayurvedic formulation developed by Solumiks Herbaceuticals Ltd., after extensive clinical research. This syrup mainly contains the extracts of Phyllanthus niruri, Ricinus communis, and Tinospora cordifolia as main components. These herbs are used in traditional medicine across the globe for their multiple health benefits, including boosting of the immune system. Individually, the herbal components of this formulation have shown immunomodulatory potential, but still, there are very few or no reports available which discuss the synergistic effects of these traditional herbs on immunomodulation in the biological system.

This research work is an effort in the direction of analyzing the cumulative impact of different herbal components in Nirocil syrup on the immune system of Wistar rats and to revive the glitter of the ancient traditional system of medicine.

\section{METHODS}

\section{Chemicals and medicine}

Nirocil syrup was obtained from Solumiks Herbaceuticals Ltd., becozinc syrup was procured from the local market (manufactured by Dr. Reddy Laboratory). Diphtheria, tetanus, and pertussis (DPT) vaccines (manufactured by Indian Immunological) were procured from the local market. Di sodium hydrogen phosphate, sodium dihydrogen phosphate, formalin, sodium acetate, sodium chloride, and sodium citrate were procured from sigma chemicals (USA).

\section{Animals}

Twenty four adult Wistar female albino rats weighing $150 \pm 15$ g. were selected for the study. The animals were housed in Committee for Purpose of Control Supervision and Experimentation on Animals (CPCSEA) approved animal house facility of Shree Dhootapapeshwar Ltd., Panvel Maharashtra (MH). The animals were maintained at $22 \pm 03^{\circ} \mathrm{C}$ with constant humidity $(50-70 \%)$ and $12 \mathrm{~h}$ day and night cycle. Animals were fed with Amrut brand rat pellet feed and water ad libitum. The experiments were carried out by prior approval from Institutional Animal Ethics Committee (Protocol No. SDARF/CT/2018/01).

\section{Dose selection and schedule}

The dose for experimental animals was deduced from the human dose and the drug solutions were administered using a gastric catheter affixed to a syringe [5].

\section{Nirocil syrup}

The human therapeutic dose of Nirocil syrup was determined as $10 \mathrm{ml}$ thrice a day, which was equivalent to $2.7 \mathrm{ml} / \mathrm{kg}$ body weight/day for rats.

\section{Becozinc syrup}

The human therapeutic dose for becozinc syrup was determined as $5 \mathrm{ml}$ a day, which was equivalent to $0.45 \mathrm{ml} / \mathrm{kg}$ body weight/day for rats.

\section{Grouping of animals}

The animals were divided into three groups having six animals each. Separate animals were utilized for humoral immunity and cell-mediated immunity study as mentioned below; 
Group 1 - Received sterile water and served as control.

Group 2 - Received Nirocil syrup for 6 weeks.

Group 3 - Received Becozinc syrup for 6 weeks and served as a positive control.

\section{Effects on humoral antibody formation}

The effect of Nirocil syrup on antibody formation against sheep red blood cells (SRBC) in Wistar female albino rats was studied as described by Puri et al. [6]. For antibody formation against SRBC in test animals, sheep blood was collected from a local slaughterhouse in a sterilized bottle. The collected blood was thoroughly washed with sterile saline through repeated centrifugation and made to $30 \%$ SRBC solution. This $30 \%$ SRBC solution was used as a sensitizing agent and made to $3 \%$ and injected subcutaneously in a dose of $0.5 \mathrm{ml} / 100 \mathrm{~g}$ of body weight to the test animals on the $35^{\text {th }}$ day of experimentation. On the $42^{\text {nd }}$ day, the blood sample was collected from test animals in a sterile tube. The serum was separated and inactivated by incubation at $56^{\circ} \mathrm{C}$ for $30 \mathrm{~min}$ in a serological water bath. Further, an antibody titer test was performed to determine the presence and the number of antibodies formed in test animals.

\section{Estimation of antibody titer}

For the estimation of antibody titer, the wells of microtiter plate were loaded with $0.1 \mathrm{ml}$ sterile normal saline and $0.1 \mathrm{ml}$ of two-fold serially diluted serum. The dilutions were made in the range of $1: 2,1: 4$, and 1:8 up to $1: 1024$. A $0.1 \mathrm{ml}$ of SRBC (3\%) was added to each well. The blood from the same animal (sheep) was used for sensitization and determination of antibody titer. The microtiter plate was shielded and then incubated overnight at $4^{\circ} \mathrm{C}$ in a refrigerator. Next day antibody titer (hemagglutination titer) was noted and converted to $\log 2$ values for comparison [7].

\section{Hematology and histopathology}

To determine the immunomodulatory effects of Nirocil syrup on experimental animals, hematological analysis was carried out. Blood samples were collected from all the surviving animals a day before initiation of dosing (basal), on completion of $5^{\text {th }}$ week (interim), and finally on $9^{\text {th }}$ week (terminal). Approximately $0.5 \mathrm{ml}$ of blood sample was collected from each experimental animal by puncturing the orbital plexus with the help of a fine glass capillary tube under the influence of light isoflurane (anesthetic). The blood samples were stored in sterile vials containing 4\% EDTA.

The following hematological parameters, total leukocyte count (white blood cell [WBC]), erythrocyte count (red blood cell [RBC]), hemoglobin $(\mathrm{Hb})$, hematocrit (HCT), mean corpuscular volume (MCV), mean corpuscular hemoglobin (MCH), mean corpuscular hemoglobin concentration (MCHC), platelet count (PLT), absolute leukocyte count, and differential leukocyte count were performed using Automated Veterinary Hematology Analyzer (DxH 600, Beckman Coulter, US).

After 6 weeks, all the surviving animals belonging to different groups were euthanized by using carbon dioxide asphyxiation. Physical examinations of animals were carried out externally.

Following this, animals were dissected and gross examination of all the internal organs was carried out. Spleen tissue of all the animals was collected and processed for histopathological (microscopic) observations.

The severity of lesions observed was recorded as no abnormality detected (NAD), minimal $(<1 \%)$, mild $(1-25 \%)$, moderate $(26-50 \%)$, moderately severe/(51-75\%), severe (76-100\%). Distribution of lesions was also recorded as focal, multifocal, and diffuse.

\section{Effect on cell-mediated immunity}

The effect of Nirocil syrup on cell-mediated immunity in Wistar albino rats was evaluated by following the procedure of Bhattacharya [8]. Animals were divided in three groups as previously described. All the animals were sensitized subcutaneously $(0.5 \mathrm{ml} / 100 \mathrm{~g}$ body weight) by $1 \mathrm{ml}$ triple antigen solution (DPT), $4 \mathrm{ml}$ normal saline $(0.9 \%)$, and $1 \mathrm{ml}$ potash alum $(10 \%)$ on $35^{\text {th }}$ day of drug administration. The $\mathrm{pH}$ of the solution was adjusted $5.6-6.8$ by $10 \%$ sodium carbonate. The drug dosing was continued for next 7 days. On the $42^{\text {nd }}$ day, $0.1 \mathrm{ml}$ of triple antigen solution was injected into plantar aponeurosis of paw after measuring of initial volume of the left hind paw. Triple antigen produced the immunological edema in rat hind paw and the paw volume of edema was measured by volume displacement method [9] at $24 \mathrm{~h}$ and $48 \mathrm{~h}$ of injection. The percentage increase in paw volume, over initial paw volume, was calculated. Cell-mediated immune response was analyzed by comparing the values of the control group versus the test drug administered group.

\section{Effects on body weight}

The effect of Nirocil syrup on the body weight of experimental animals was also studied. The bodyweight of experimental animals of different groups was recorded on every $7^{\text {th }}$ day till the completion of the study.

\section{Statistical analysis}

Results were presented as mean \pm SEM, difference between the groups was statistically determined by one-way ANOVA with post hoc Tukey HSD test with the level of significance set at $p<0.05$. The significance of level was noted and interpreted accordingly.

\section{RESULTS}

\section{Body weight}

The effect of Nirocil syrup on the body weight of experimental animals of different groups is presented in Table 1. On comparison to the control group of animals, there was a significant increase $(\mathrm{p}<0.01)$ in body weight in Nirocil treated group and becozinc treated group.

\section{Hematology}

The results of hematological analysis of all the experimental groups at different time intervals are presented in Table 2A-C. A slight increase in total WBC count $(10.33-11.38 / \mu \mathrm{l})$ and absolute lymphocyte count $(8586.30 \pm 340.00$ cells $/ \mu \mathrm{l})$ was observed in Nirocil treated groups after 5 weeks in comparison to 0 days $(7884.30 \pm 198.04)$. However, no major changes were observed in other hematological parameters. A significant increase in total WBC count and absolute lymphocyte count $(12630.3 \pm 488$ cells/ $\mu$ l) was observed only after 9 weeks in Nirocil treated groups, compared to the control group. Whereas, the becozinc treated group showed similar results $(12234.5 \pm 550.0$ cells $/ \mu \mathrm{l})$ (Table 2C), suggesting increased immune response in both Nirocil and becozinc treated groups.

\section{Humoral antibody formation}

The effect of Nirocil on antibody titer formation against SRBC in Wistar female albino rats is presented in Table 3. Nirocil treated groups showed a significant $\left({ }^{* *} \mathrm{p}<0.01\right)$ increase in antibody titer formation in comparison to the control group. The increase of antibody titer formation in the Nirocil treated group was observed $48.22 \%$, which was comparable to the titer formation in the becozinc treated group (48.21\%). On comparing the titer formation between the groups (Nirocil vs. Becozinc) the result was not significant at $\mathrm{p}<0.05$, as both the groups showed a similar increase in titer formation.

Lymphocytes are the cells involved in adaptive immunity and subdivided into B, T, and NK lymphocytes [10]. Leukocyte count analysis showed a significant increase $(* \mathrm{p}<0.05)$, specifically total lymphocytes count in Nirocil and becozinc treated groups. This suggests the increased immune stimulation in the treated group of animals in comparison to the control group. These results are in agreement with the findings of Ketema et al. [11] indicated a synergism between increased lymphocyte counts and elevated immune response.

\section{Histopathology}

The microscopic examination of the spleen tissue of the control group of animals did not show any lesion of pathological significance (Fig. 1a). 
Table 1: Effect of Nirocil syrup on body weight of experimental animals

\begin{tabular}{llllll}
\hline Animal no. & Control group (weight in g) & Animal no. & Nirocil group (weight in g) & Animal no. & Becozinc group (weight in g) \\
\hline 1 & 185 & 7 & 201 & 13 \\
2 & 184 & 8 & 204 & 14 & 198 \\
3 & 194 & 9 & 198 & 16 & 201 \\
4 & 192 & 10 & 200 & 17 & 13 \\
5 & 194 & 11 & 198 & 18 & 204 \\
6 & 193 & & 200 & 201 \\
Mean & 190.3333 & & & \\
\hline
\end{tabular}

Table 2A: Individual animal hematology analysis on 0 day

\begin{tabular}{|c|c|c|c|}
\hline Parameters & Control group & Nirocil group & Becozinc group \\
\hline WBC $(\mathrm{X} 103 / \mu \mathrm{L})$ & $10.13 \pm 0.39$ & $10.00 \pm 0.23$ & $10.22 \pm 0.13$ \\
\hline $\mathrm{RBC}(\mathrm{X} 106 / \mu \mathrm{L})$ & $7.05 \pm 0.09$ & $7.56 \pm 0.29$ & $7.33 \pm 0.33$ \\
\hline $\mathrm{Hgb}(\mathrm{g} / \mathrm{dL})$ & $13.87 \pm 0.3$ & $14.28 \pm 0.40$ & $14.05 \pm 0.31$ \\
\hline HCT $(\%)$ & $42.05 \pm 0.84$ & $42.17 \pm 0.80$ & $41.10 \pm 0.65$ \\
\hline $\operatorname{MCV}(\mathrm{fl})$ & $59.7 \pm 0.93$ & $56.20 \pm 2.02$ & $56.83 \pm 2.94$ \\
\hline $\mathrm{MCH}(\mathrm{pg})$ & $19.67 \pm 0.48$ & $19.00 \pm 0.67$ & $19.30 \pm 0.65$ \\
\hline MCHC (g/dL) & $33.02 \pm 0.68$ & $33.87 \pm 0.55$ & $34.28 \pm 1.29$ \\
\hline Absolute neutrophil count (cells $/ \mu \mathrm{L}$ ) & $1823.50 \pm 83.40$ & $1752.00 \pm 101.01$ & $1924.30 \pm 69.80$ \\
\hline Absolute lymphocyte count (cells $/ \mu \mathrm{L}$ ) & $7900.80 \pm 382.20$ & $7884.30 \pm 198.04$ & $7900.80 \pm 112.02$ \\
\hline Absolute monocyte count (cells $/ \mu \mathrm{L}$ ) & $189.80 \pm 36.31$ & $180.50 \pm 24.20$ & $204.70 \pm 25.30$ \\
\hline Absolute eosinophil count (cells $/ \mu \mathrm{L}$ ) & $219.20 \pm 33.64$ & $183.20 \pm 29.30$ & $186.80 \pm 27.70$ \\
\hline Neutrophil (\%) & $18.17 \pm 1.19$ & $17.50 \pm 0.84$ & $18.83 \pm 0.64$ \\
\hline Lymphocyte (\%) & $77.83 \pm 1.01$ & $78.83 \pm 0.54$ & $77.33 \pm 0.45$ \\
\hline Monocyte (\%) & $1.83 \pm 0.30$ & $1.83 \pm 0.28$ & $2.00 \pm 0.23$ \\
\hline Eosinophil (\%) & $2.17 \pm 0.30$ & $1.83 \pm 0.28$ & $1.83 \pm 0.28$ \\
\hline
\end{tabular}

WBC: White blood cells, RBC: Red blood cells, Hgb: Hemoglobin, HCT: Hematocrit, MCV: Mean corpuscular volume, MCHC: Mean corpuscular hemoglobin count, PLT: Platelets

Table 2B: Individual animal hematology analysis on $5^{\text {th }}$ week

\begin{tabular}{|c|c|c|c|}
\hline Parameters & Control group & Nirocil group & Becozinc group \\
\hline WBC $(\mathrm{X} 103 / \mu \mathrm{L})$ & $10.32 \pm 0.27$ & $10.90 \pm 0.33$ & $11.38 \pm 0.26$ \\
\hline $\mathrm{RBC}(\mathrm{X} 106 / \mu \mathrm{L})$ & $7.14 \pm 0.03$ & $7.32 \pm 0.16$ & $7.27 \pm 0.18$ \\
\hline $\mathrm{Hgb}(\mathrm{g} / \mathrm{dL})$ & $14.62 \pm 0.18$ & $14.55 \pm 0.27$ & $14.57 \pm 0.33$ \\
\hline HCT $(\%)$ & $42.05 \pm 0.83$ & $42.17 \pm 0.80$ & $41.10 \pm 0.65$ \\
\hline MCV (fl) & $58.78 \pm 1.29$ & $57.70 \pm 1.11$ & $56.78 \pm 1.95$ \\
\hline $\mathrm{MCH}(\mathrm{pg})$ & $20.47 \pm 0.18$ & $19.92 \pm 0.46$ & $20.05 \pm 0.34$ \\
\hline $\operatorname{MCHC}(\mathrm{g} / \mathrm{dL})$ & $34.85 \pm 0.89$ & $34.55 \pm 0.57$ & $35.57 \pm 1.34$ \\
\hline Absolute neutrophil count (cells $/ \mu \mathrm{L}$ ) & $2071.80 \pm 150.00$ & $1876.50 \pm 82.90$ & $1955.80 \pm 107.00$ \\
\hline Absolute lymphocyte count (cells $/ \mu \mathrm{L}$ ) & $7884.30 \pm 171.00$ & $8586.30 \pm 340.00$ & $8976.80 \pm 249.00$ \\
\hline Absolute monocyte count (cells $/ \mu \mathrm{L}$ ) & $206.50 \pm 28.00$ & $254.80 \pm 34.40$ & $282.70 \pm 19.90$ \\
\hline Absolute eosinophil count (cells $/ \mu \mathrm{L}$ ) & $154.00 \pm 22.60$ & $182.30 \pm 22.70$ & $168.00 \pm 19.90$ \\
\hline Neutrophil (\%) & $20.00 \pm 1.15$ & $17.33 \pm 0.99$ & $17.17 \pm 0.79$ \\
\hline Lymphocyte (\%) & $76.50 \pm 0.99$ & $78.67 \pm 1.14$ & $78.83 \pm 0.86$ \\
\hline Monocyte (\%) & $2.00 \pm 0.25$ & $2.33 \pm 0.30$ & $2.50 \pm 0.20$ \\
\hline Eosinophil (\%) & $1.50 \pm 0.22$ & $1.67 \pm 0.19$ & $1.50 \pm 0.20$ \\
\hline
\end{tabular}

WBC: White blood cells, RBC: Red blood cells, Hgb: Hemoglobin, HCT: Hematocrit, MCV: Mean corpuscular volume, MCHC: Mean corpuscular hemoglobin count, PLT: Platelets

While the spleen tissue of Nirocil treated, group showed various lesions of multifocal mild to the moderate category in four out of six animals (Fig. 1b). Whereas, the spleen tissue of the becozinc treated control group showed multifocal moderate extramedullary hematopoiesis in two out of six animals (Fig. 1c). The presence of splenic extramedullary hematopoiesis suggested the antigenic stimulation in treated groups as it is reported for the production of antigen-presenting cells and phagocytes in the spleen [12-15].

\section{Effect on cell-mediated immunity}

The effect of Nirocil syrup on immunological paw edema in triple antigen sensitized rats is shown in Table 4. A gradual increase in paw volume was observed in all the groups starting from $0 \mathrm{~h}$ to $48 \mathrm{~h}$. After $48 \mathrm{~h}$, the paw volume was found significantly lower in Nirocil treated group (1.508 $\mathrm{ml}$ ) and becozinc $(1.41 \mathrm{ml})$ treated group in comparison to the control group $(1.673 \mathrm{ml})$. The results indicate that Nirocil is involved in lowering edema/inflammation induced by cell-mediated immune response.

\section{DISCUSSION}

Nirocil syrup is an Ayurvedic formulation contains the extracts of P. niruri, R. communis, and T. cordifolia as the main component. They are the multipurpose folkloric medicinal plants with manifold biological activities; anticancer, antidiabetic, anti-inflammatory, antimalarial, antioxidant, central analgesic, anticonvulsant, antinociceptive, anthelminthic, antifertility, laxative, uterine contracting, antiimplantation, antiasthmatic, bone regeneration, molluscicidal, antiulcer, antihistamine, wound-healing, cytotoxic, insecticidal, anti-arthritic, antidandruff, hepatoprotective, and immunomodulatory properties [16]. Before the discovery of chemical and synthetic compounds, these plants 
Table 2C: Individual animal hematology analysis on $9^{\text {th }}$ week

\begin{tabular}{|c|c|c|c|}
\hline Parameters & Control group & Nirocil group & Becozinc group \\
\hline 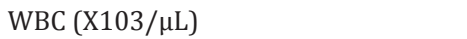 & $10.25 \pm 0.22$ & $14.62 \pm 0.50$ & $14.42 \pm 0.60$ \\
\hline $\mathrm{RBC}(\mathrm{X} 106 / \mu \mathrm{L})$ & $7.18 \pm 0.14$ & $7.37 \pm 0.19$ & $7.33 \pm 0.17$ \\
\hline $\mathrm{Hgb}(\mathrm{g} / \mathrm{dL})$ & $14.37 \pm 0.17$ & $14.6 \pm 0.22$ & $14.77 \pm 0.21$ \\
\hline HCT $(\%)$ & $42.05 \pm 0.83$ & $42.17 \pm 0.80$ & $41.1 \pm 0.65$ \\
\hline $\mathrm{MCV}(\mathrm{fl})$ & $58.57 \pm 0.76$ & $57.38 \pm 1.43$ & $56.3 \pm 1.65$ \\
\hline $\mathrm{MCH}(\mathrm{pg})$ & $20.05 \pm 0.56$ & $19.87 \pm 0.38$ & $20.2 \pm 0.47$ \\
\hline $\mathrm{MCHC}(\mathrm{g} / \mathrm{dL})$ & $34.25 \pm 0.99$ & $34.68 \pm 0.69$ & $36.03 \pm 1.00$ \\
\hline Absolute neutrophil count (cells/ $\mu \mathrm{L}$ ) & $2079.5 \pm 82.20$ & $1455.2 \pm 91.40$ & $1679.3 \pm 163.00$ \\
\hline Absolute lymphocyte count (cells $/ \mu \mathrm{L}$ ) & $7739 \pm 216.00$ & $12630.3 \pm 488.0^{a *}$ & $12234.5 \pm 550.0^{\mathrm{a} *}$ \\
\hline Absolute monocyte count (cells $/ \mu \mathrm{L}$ ) & $189.2 \pm 34.60$ & $308.8 \pm 40.70$ & $267.7 \pm 47.90$ \\
\hline Absolute eosinophil count (cells/ $\mu \mathrm{L}$ ) & $205.3 \pm 27.70$ & $222.3 \pm 34.00$ & $235.2 \pm 37.20$ \\
\hline Neutrophil (\%) & $20.33 \pm 0.91$ & $10 \pm 0.62$ & $11.67 \pm 0.99$ \\
\hline Lymphocyte (\%) & $75.5 \pm 1.33$ & $86.33 \pm 0.69$ & $84.83 \pm 1.09$ \\
\hline Monocyte (\%) & $1.83 \pm 0.30$ & $2.17 \pm 0.36$ & $1.83 \pm 0.28$ \\
\hline Eosinophil (\%) & $2 \pm 0.25$ & $1.5 \pm 0.20$ & $1.67 \pm 0.30$ \\
\hline
\end{tabular}

WBC: White blood cells, RBC: Red blood cells, Hgb: Hemoglobin, HCT: Hematocrit, MCV: Mean corpuscular volume, MCHC: Mean corpuscular hemoglobin count,

PLT: Platelets. ${ }^{a *}$ Significance change when compare with control

Table 3: Effect of Nirocil and becozinc on hemagglutination titer in SRBC pre-sensitized rats

\begin{tabular}{llll}
\hline Group & Ha titer & $\begin{array}{l}\text { Log2 } \\
\text { value }\end{array}$ & $\begin{array}{l}\text { Percentage increase of ha } \\
\text { titer as per log2 value }\end{array}$ \\
\hline Control & $53.330 \pm 6.158$ & 5.7368 & - \\
Nirocil & $362.667 \pm 63.404^{\text {a* }}$ & 8.5025 & $48.21 \uparrow$ \\
Becozinc & $362.667 \pm 63.404^{\text {a* }}$ & 8.5025 & $48.21 \uparrow$ \\
\hline
\end{tabular}

The data are expressed as mean \pm SEM of $n=6$. Significant differences in treated group versus control group are ${ }^{*} \mathrm{p}<0.05$. ${ }^{\mathrm{a} *}=$ versus control

Table 4: Effect of Nirocil syrup on immunological paw edema in triple antigen sensitized rats

\begin{tabular}{lcccc}
\hline Group & \multicolumn{3}{c}{ Paw volume in ml } & \multirow{2}{*}{$\begin{array}{c}\text { Percentage } \\
\text { increase }\end{array}$} \\
\cline { 2 - 4 } & $\mathbf{0 ~ h}$ & $\mathbf{2 4 ~ h}$ & $\mathbf{4 8 ~ h}$ & \\
\hline Control & $1.188 \pm 0.0210$ & $1.585 \pm 0.0280$ & $1.673 \pm 0.031$ & 41.52 \\
Nirocil & $1.162 \pm 0.0086$ & $1.4 \pm 0.0160^{*}$ & $1.508 \pm 0.013^{*}$ & 29.84 \\
Becozinc & $1.125 \pm 0.0069$ & $1.333 \pm 0.0148^{*}$ & $1.41 \pm 0.024^{*}$ & 41.52 \\
\hline \multicolumn{4}{l}{ The data are expressed as mean $\pm \mathrm{SEM}$ of $\mathrm{n}=6$. Significant difference in treated } \\
group versus control group is * $\mathrm{p}<0.05$
\end{tabular}

played a significant role in traditional medicine for curing various diseases throughout the world [3]. The current research work was planned to evaluate immunomodulatory potential all components in syrup.

As far as the immunomodulatory property of these plants is concerned, $P$. niruri has scientifically been studied and evaluated in various clinical trials on infectious diseases, such as chronic hepatitis B $[5,17]$, pulmonary tuberculosis (TB) $[10,11,18,19]$, vaginitis [20], as well as varicella-zoster infection [21]. In such diseases, the effective immune system is crucial for the treatment and successful eradication of pathogens [19,22]. Ma'at (1996) reported the enhancement in activity and functioning of the immune system by $P$. niruri extract through stimulation of natural killer (NK) cell cytotoxicity, secretion of tumor necrosis factor (TNF- $\alpha$ ), and decreased interleukin (IL-10) secretions. Thus, P. niruri modulates both humoral and cellular immunity [19]. In Mycobacterium tuberculosis infection, IFN- $\gamma$ is biologically involved in the activation of macrophages. In recent reports, the aqueous extract of $P$. niruri showed induction of proliferation of peripheral blood mononuclear cells (PBMCs) and phagocytic activity of macrophages in patients suffering from tuberculosis [23]. A significant elevation of plasma IFN- $\gamma$ level was observed after 2 months of concomitant treatment with $P$. niruri $[24,25]$. Findings in our study reconfirm this phenomenon which is reflected in terms of an increase in antibody

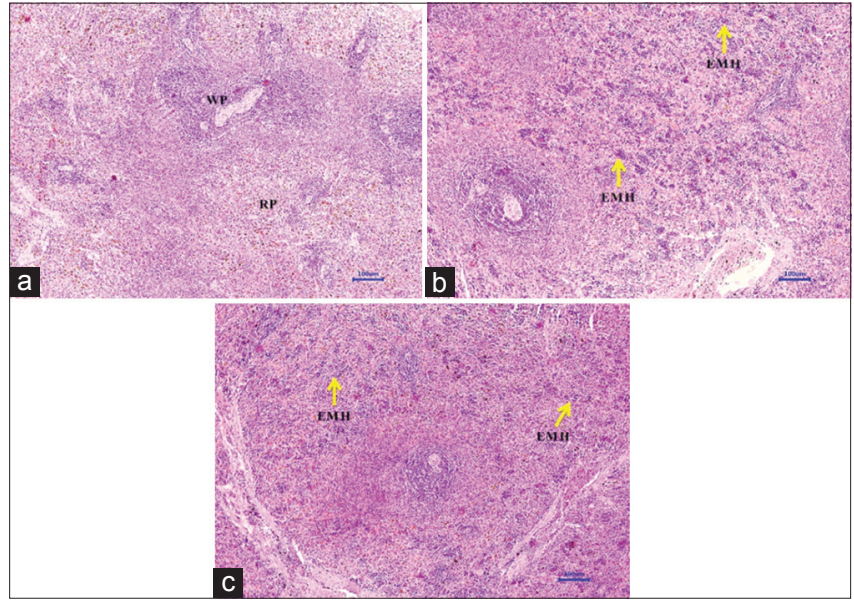

Fig. 1: Microscopic section of spleen tissue stained with $H$ and

E stain. (a) Control group: Showing normal histology, WP, RP,

(b) Nirocil treated group: Showing EMH in red pulp. (c) Becozinc treated group: Showing extramedullary hematopoiesis in red pulp (EMH). WP: White pulp, RP: Red pulp, EMH: Extramedullary hematopoiesis

titer in rats treated with Nirocil syrup. Increase in antibody titer [26]. In line with such findings, $T$. cordifolia is reported to mediate immunomodulatory action through activating the macrophage innate immune system. Macrophages showed high phagocytosis and pinocytic rate when treated with $T$. cordifolia extract. More and Pai [27] have reported a significant enhancement in phagocytosis after T. cordifolia treatment. Aher et al. reported the rise in WBC and serum antibody concentrations in experimental animals treated with alcoholic extract of T. cordifolia, confirming the immunomodulatory potential [28].

The humoral antibody response is mediated by an antibody produced by B-lymphocytes. Agglutination is a result of an antigen-antibody reaction. The relative strength of an antibody titer is defined as the reciprocal of the highest dilution with detectable agglutination [6]. The antibody titer is an indicator of the changes in the amount of the antibody in the course of an immune response [29].

Per oral administration of the Nirocil syrup produced an increase in the antibody titer in rats in the Nirocil treated group when compared to the control group (Table 3). This phenomenon is supported by an increase in lymphocyte count in Nirocil treated group [30]. Furthermore, the presence of splenic extramedullary hematopoiesis suggestive of 
antigenic stimulation in Nirocil and Balchaturbhadrika treated groups when compared to the control group [31].

An increase in body weight is indicative of normal health status of the organism, while reduced body weight indicates abnormal health status and degenerative changes in the body. [19]. In the present study, the animals of Nirocil treated group showed a significant increase in their body weight compared to the control group which reflects the good health status of experimental animals.

These findings indicate that the Nirocil syrup has antibody enhancing effects. The possible mode of action for the enhancement of antibody titer may be attributed to the synergistic effects of phytochemical constituents of $P$. niruri, $R$. communis, and T. cordifolia through accelerating the processing of antigen by macrophages, enhanced secretion of cytokines, and tissue growth factor, which might have stimulated the B-lymphocytes proliferation.

\section{CONCLUSIONS}

P. niruri, R. communis, and T. cordifolia have been explored individually by various researchers for their multiple health benefits. In the present study, immunomodulatory potential of Nirocil syrup has been studied which contains all these herbs as an active constituent. Nirocil syrup showed antibody enhancing effects by increasing the serum antibody titer, absolute lymphocyte count, and formation of extramedullary hematopoiesis in spleen tissue of experimental rats. In the triple antigen-induced immunological edema model, Nirocil treated group of animals showed suppression of paw edema volume by lowering the inflammation induced by the cell-mediated immune response. The present study concludes that Nirocil syrup has immunopotentiating activity.

\section{ACKNOWLEDGMENT}

\section{AUTHORS' CONTRIBUTIONS}

All authors contributed equally in research activities and manuscript writing.

\section{CONFLICTS OF INTEREST}

None.

\section{AUTHORS' FUNDING}

We are very grateful to Shree Dhootapapeshwar Limited, Panvel, Maharashtra, for financial support (SDARF/CT/2018/01).

\section{REFERENCES}

1. Jadavaji T. In: Agnivesha, Samhita C, editors. Chaukhambha Sanskrit Sansthan, Sutrasthana. Ch. 28. Varanasi: Ayurveda Dipika Commentary of Chakrapani Datta; 2004.

2. Patwardhan B, Warude D, Pushpangadan P, Bhatt N. Ayurveda and traditional Chinese medicine: A comparative overview. Evid Based Complement Alternat Med 2005;2:465-73.

3. Sehar I, Kaul A, Bani S, Pal HC, Saxena AK. Immune up-regulatory respose of a non-caloric natural sweetener, stevioside. Chem Biol Interact 2008; 173:115-21.

4. Agrawal SS, Khadase SC, Talele GS. Studies on immunomodulatory activity of Capparis zeylanica leaf extracts. Int J Pharm Sci Nanotechnol 2010;3:887-92.

5. Paget GE, Barnes JM. Toxicity tests. In: Laurence DR, Bacharach AL, editors. Evaluation of Drug Activities: Pharmacometrics. Vol. 1. London: Academic Press; 1964. p. 135.

6. Puri A, Saxena R, Saxena RP, Saxena KC, Srivastava V, Tandon JS. Immunostimulant activity of Nyctanthes arbor-tristis L. J Ethnopharmacol 1994;42:31-7.
7. Khan T, Tatke P, Gabhe SY. Immunological studies on the aerial roots of the Indian Banyan. Indian J Pharm Sci 2008;70:287-91.

8. Bhattacharya Manual Pre-conference. Annual Conference of Indian Pharmacological Society. Kolkata: Workshop on Research Methodology in Pharmacology; 1993.

9. Shejawal N, Menon S, Shailajan S. A simple, sensitive and accurate method for rat paw volume measurement and its expediency in preclinical animal studies. Hum Exp Toxicol 2014;33:123-9.

10. Janeway CA, Travers P, Walport M, Shlomchik MJ. Immunobiology. $6^{\text {th }}$ ed. Garland: Science; 2005.

11. Ketema T, Yohannes M, Alemayehu E, Ketema AA. Evaluation of immunomodulatory activities of methanolic extract of Khat (Catha edulis, Forsk) and cathinone in Swiss albino mice. BMC Immunol 2015;16:1-11.

12. Boorman GA, Eustis SL, Elwell MR, Montgomery CA Jr., MacKenzie WF. Pathology of the Fischer Rat: Reference and Atlas. New York, Boston, London, Sydney, Tokyo, Torento: Academic Press, Inc.; 1990.

13. Greaves P. Histopathology of Preclinical Toxicity Studies. $3^{\text {rd }}$ ed. New York: Academic Press/Elsevier; 2007. p. 466.

14. Vos JG, Kimber I, Kuper CF, van Loveren H, Shuurman HJ. The immune system. In: Turton J, Hooson J, editors. Target Organ Pathology: A Basic Text. London: Taylor and Francis Publications; 1998.

15. Chang K. Homeostatic and pathogenic extramedullary hematopoiesis. J Blood Med 2010;3:13-9.

16. Lee NY, Khoo WK, Adnan MA, Mahalingam TP, Fernandez AR, Jeevaratnam K. The pharmacological potential of Phyllanthus niruri. J Pharm Pharmacol 2016;68:953-69.

17. Prasad AS. Zinc in human health: Effect of zinc on immune cells. Mol Med 2008;14:353-7.

18. Yadav SS, Galib, Prajapati PK, Ashok BK, Ravishankar B. Evaluation of immunomodulatory activity of shirishavaleha-an ayurvedic compound formulation in albino rats. J Ayurveda Integr Med 2011;2:192-6.

19. Tjandrawinata RR, Liana WS, Dwi N. The use of Phyllanthus niruri L. As an immunomodulator for the treatment of infectious diseases in clinical settings. Asian Pac J Trop Dis 2017;7:132-40.

20. Sari AB, Wahyudi T, Misnawi, Mufida DC, Suardita IA. Macrophage activity and capacity following oral administration of cocoa extract to mice. Procedia Chem 2016;18:122-6.

21. Abdul WM, Hajrah NH, Sabir JS, Al-Garni SM, Sabir MJ, Kabli SA, et al. Therapeutic role of Ricinus communis L. and its bioactive compounds in disease prevention and treatment. Asian Pac J Trop Med 2018;11:177-85.

22. Verma M, Kumar A. Antimicrobial activity of some folk medicinal plants used in Rajasthan against selected pathogenic microorganisms. Int J Curr Pharm Res 2017;9:84-6.

23. Putri DU, Rintiswati N, Soesatyo MH, Haryana SM. Immune modulation properties of herbal plant leaves Phyllanthus niruri aqueous extract on immune cells of tuberculosis patient-in vitro study. Nat Prod Res 2018;2:463-7.

24. Lyadova IV, Panteleev AV. Th1 and Th17 cells in tuberculosis: Protection, pathology, and biomarkers. Med Inflamm 2015;2015:854507.

25. Radityawan D. The modulatory effect of Phyllanthus niruri on serum IFN-g level in pulmonary tuberculosis patients. Dexa Media 2005; 18:94-6.

26. Wagle NS, Nagarjuna A, Sudheer C, Roopesh HP, Sapkota NB, Dangi NB, et al. Evaluation of immunomodulatory activity of petroleum ether extract of seeds of Pithecellobium dulce in Wistar rats. Int J Pharm Pharm Sci 2015;7:471-9.

27. More P, Pai K. Effect of Tinospora cordifolia (Guduchi) on the phagocytic and pinocytic activity of murine macrophages in vitro. Indian J Exp Biol 2017;55:21.

28. Aher VD, Wahi AK. Pharmacological study of Tinospora cordifolia as an immunomodulator. Int J Curr Pharm Res 2010;2:52-4.

29. Shrestha P, Handral M. Evaluation of immunomodulatory activity of extract from rind of Nephelium lappaceum fruit. Int J Pharm Pharm Sci 2016;9:38-43.

30. Sun Z, Shi L, Zhang H, Shao Y, Wang Y, Lin Y, et al. Immune modulation and safety profile of adoptive immunotherapy using expanded autologous activated lymphocytes against advanced cancer. Clin Immunol 2011;138:23-32.

31. Kim CH. Homeostatic and pathogenic extramedullary hematopoiesis. J Blood Med 2010;1:13-9. 